\title{
The Effects of Ketapang (Terminalia catappa) Bark Crude Extract on Inhibition of Aeromonas hydrophila Growth and Blood Cells of the Infected Carp (Cyprinus carpio)
}

\author{
Maftuch $^{1}$, Heny Suprastyani ${ }^{2}$, Ellana Sanoesi ${ }^{3}$, Gede A. A. K. Putra ${ }^{4}$, \\ Mirsa F. Putra ${ }^{5}$, Asep A. Prihanto 6 \\ 1,2,3,4,5 Department of Aquaculture, Faculty of Fisheries and Marine Science, \\ University of Brawijaya \\ ${ }^{6}$ Department of Fishery Product Technology, Faculty of Fisheries and Marine \\ Science, University of Brawijaya \\ 1maftuch@ub.ac.id
}

\begin{abstract}
The objectives of the research were to investigate the effect of ketapang (Terminalia catappa) bark crude extract (KBCE) on Aeromonas hydrophila growth and blood cells of the A. hydrophila-infected carp (Cyprinus carpio). The Research was conducted by using completely randomized design. There were four (750, 850,950 , and 1,050 ppm) and three treatments (730, 750, and $770 \mathrm{ppm}$ ) were used for in vitro and in vivo experiments respectively. Data were analyzed by analysis of variation and LSD. The dose to investigate MIC of KBCE were 750, 850, 950 and 1,050 ppm. The MIC of KBCE was 750 ppm. On in vivo investigation, number of erythrocytes were $224.67 \times 10,332.67 \times 10$, and $417.00 \times 10 \mathrm{cells} / \mathrm{mm}$ for 730, 750 and 770 ppm KBCE, respectively. For leukocytes, the amount were $735.89 \times 10,684.78 \times 10$, and $652.67 \times 10 \mathrm{cell} / \mathrm{mm}$ for 730,750 and $770 \mathrm{ppm} \mathrm{KBCE}$, respectively. In addition, the water quality were as follows $24.0-25.9 \square C$ of temperature, $7.0-7.7 \mathrm{of} \mathrm{pH}$, and $3.9-4.8 \mathrm{mg} / \mathrm{L}$ of $\mathrm{DO}$. In conclusion, we revealed that KBCE able to act as antibacterial against $A$. hydrophila. Furthermore, it also induced the total erythrocyte in infected fish without giving a notable effect on water quality.
\end{abstract}

Keywords: Ketapang bark; Aeromonas hydrophila; carp; erythrocytes; leukocytes

\section{INTRODUCTION}

Indonesia is a country which has vast potential of fisheries natural resources. It has been proven by the fisheries commodity exported to USA market which increased up to 25.19\% during 2014-2015 (MMAF, 2015).

The fisheries potential in Indonesia is obtained from wild fisheries and fish farming. However, the result of wild fisheries is getting lower. Thus, the products of fish farming are expected to support the fisheries export in the future. The types of fish farming in Indonesia can be divided into mariculture, pond culture, freshwater pond culture, and rice-fish field culture (Gusrina, 2008).

The main problem faced by the fish farmer is fish diseases. Fish disease in pond is the result of mismatch interaction between fish, environmental condition and disease organisms (Snieszko 1973). This 
mismatch interaction can cause the fish becomes stressful. That condition will decreases fish defense mechanism which makes it easy to be infected with disease. The infection of certain disease caused by bacteria is the main problem in fish farming process (Bondad et al., 2005).

A. hydrophila is potential pathogenic bacteria for fish. This pathogen can attack the fish under these following conditions; imbalanced nutrition contained in the fish fodder, high level of organic contained in the water environment, high level of water quality parameter fluctuation, secondary infection caused by parasite and genetic factor (low immunity of fish can be infected by bacteria) (Cipriano, 2001).

An attempt that has been done to cure the fish disease is the use of antibiotics which later on causing pathogenic bacteria resistance and antibiotic residues (Shak et al., 2011). Therefore, there is a need for alternative development of antibacterial substance made from medicinal plants, as known as phytochemical. Indonesian local plants have been known to produce antibacterial substances (Prihanto et al., 2012; Purwani et al., 2015).In this study we investigated the effect of Ketapang (Terminalia catappa) bark extract on the growth of $A$. hydrophila, and on blood cells of the infected carp.

\section{MATERIALS AND METHODS}

Common Carp (C. carpio) was obtained fromPunten Batu East Java, fish with the size of $7-11 \mathrm{~cm}$, Ketapang (T. catappa) was collected from Location near University. A. hydrophila was obtained from Fish Quarantine and Inspection Agency
Class I, Surabaya, East Java, Indonesia.

\section{Preparation of Ketapang Bark Crude Extract (KBCE)}

Ketapang bark crude extract used the modification method from Sumino et al. (2013), it was done by adding $96 \%$ ethanol to grinded Ketapang bark with ratio of $5: 1$. This maceration process was done for three days on dark place. Filtered extract was evaporated by using rotary evaporator under temperature of $45^{\circ} \mathrm{C}$.

\section{Minimum Inhibitory Concentration (MIC)}

The MIC were investigated following the method of Akinyemi et al., (2006) with slight modification. The MIC were determined by diluting the KBCE with various concentrations $(750,850,950$, and $1,050 \mathrm{ppm})$. Specifically $0.1 \mathrm{ml}$ of standardized inoculums of $10 \times 109$ $\mathrm{cfu} / \mathrm{ml}$ was added to each tube. The tubes were incubated at $30 \stackrel{\circ}{\circ}$ for 24 hours. MIC was determined as the lowest concentration of the extracts permitting no visible growth (no turbidity). The inhibiton zone was also investigated in all doses of KBCE. Different doses of $100 \mu \mathrm{l}$ of KBCE extracts were loaded in each wells. After 24 hour at $30^{\circ} \mathrm{C}$, the clear zone was measured.

\section{Bacterial Infection on Fish}

Each aquarium was filled with 10 fish. Infection of $A$. hydrophila bacteria to the carp (C. carpio) was done by soaking the fish in aquarium equipped with aeration and 20 water. Thus, the used dilution formula was described on equation 1. Infection process was performed for 24 
Tabel 1. Absorbance values of each dose based on MIC Test by Spectrophotometer

\begin{tabular}{cccc}
\hline No. & Doses & Absorbance & Remarks \\
\hline 1 & $750 \mathrm{ppm}$ & 0.160 & clear \\
2 & $800 \mathrm{ppm}$ & 0.530 & clear \\
3 & $850 \mathrm{ppm}$ & 0.198 & clear \\
4 & $900 \mathrm{ppm}$ & 0.095 & clear \\
5 & $950 \mathrm{ppm}$ & 0.200 & clear \\
6 & $1000 \mathrm{ppm}$ & 0.595 & clear \\
7 & $1050 \mathrm{ppm}$ & 0.123 & clear \\
8 & Control (-) & 0.358 & Not clear \\
9 & Control $(+)$ & 0.151 & clear \\
\hline
\end{tabular}

Notes: A.hydrophila as Control (-); A. hydrophila was grown on the medium of $100 \%$ KBCE as Control (+)

hours. Then, the fish was removed to the fresh water and cured with KBCE for six minutes soaking. Each dose was 730,750 , and 770 ppm.

\section{Haematology Analysis}

Hematological parameters Red blood cell (erythrocyte) and White blood cell (leukocyte) was counted with hemocytometer technique according to Mones (2008) with modification. Approximately $1 \mathrm{~mL}$ of blood was collected from carp caudal peduncle containing $0.5 \mathrm{mg}$ ethylene diamine tetra acetic acid (EDTA), for preventing coagulation. The detail analysis were explained elsewhere (Mones, 2008).

\section{Data Analysis}

Data were analyzed by Analysis of variance (ANOVA). If there were significances between each treatment, Post hoc of Least Significance Different (LSD) is used to see differences for each treatment. Results were considered to be significant when $\mathrm{p}<0.05$.

\section{RESULT AND DISCUSSION Minimum Inhibitory Concentration (MIC)}

MIC test was performed by using several doses of ketapang bark crude extract (KBCE). It was aimed to know the lowest dose of KBCE to inhibit the growth of $A$. hydrophila. The result was described in the Table 1.

Based on the spectrophotometer result in dose of $750 \mathrm{ppm}$, the absorbance value was 0.160 . That value was close to value of the positive control (0.151). The result of MIC test was observed by clear color change for the first time which showed that the positive control was closed to $750 \mathrm{ppm}$. It indicated that the dose of $750 \mathrm{ppm}$ could inhibit the growth of $A$. hydrophila.

Ketapang is plant with rich phytochemical compounds. Ketapang is known to have medicinal compound such as flavonoid, tannin, triterpenoid/steroid, resin and saponin which categorized as antibacterial compound (Riskitavani and Kristanti, 2013). In accordance to the statement from Harborne (1998) and Thompson et al., (2006), based on 


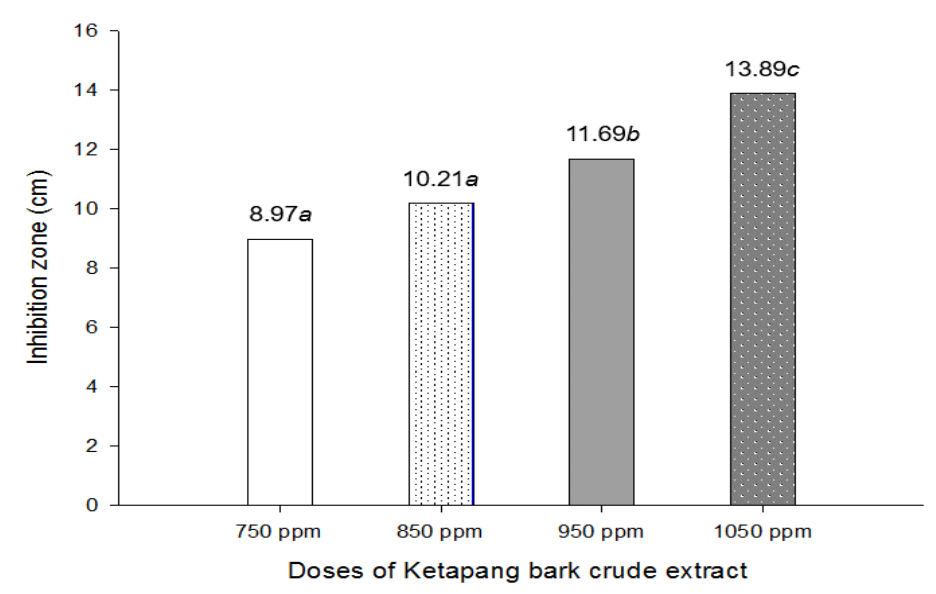

Fig. 1: The Relation between doses of Ketapang bark crude extract and the diameter of inhibition zone of $A$. hydrophila. Data are represented as mean $(n=12)$. Different letters indicate significant differences $(P<0.01)$ among four treatments determined by one-way ANOVA and continued by LSD $5 \%$.

phytochemical test, bark positively contained phenolic, tannin, flavonoid, alkaloid, terpene and steroid.

Based on the observation, the average diameter of the smallest inhibition zone in KBCE at $750 \mathrm{ppm}$ was $8.97 \mathrm{~mm}$, meanwhile the average diameter of the biggest inhibition zone was at $1,050 \mathrm{ppm}$ for $13.89 \mathrm{~mm}$. Analysis of variance (ANOVA) test showed significant difference between treatments $(p<0.01)$.

Based on Fig. 1, it could be seen that the use of KBCE could inhibit the growth of $A$. hydrophila; the average diameter of inhibition zone ranged between 8.97 and $13.89 \mathrm{~mm}$ which indicated that KBCE had strong antibacterial activity. Related to Ismaini (2007), he classifies the inhibition zone of antibacterial activity into low activity $(<5 \mathrm{~mm})$, medium activity $(5-10 \mathrm{~mm})$, strong activity $(11-20 \mathrm{~mm})$, and very strong activity ( $>20 \mathrm{~mm}$ ), KBCE can be classified as medium (750 ppm) and strong activities (850, 950 and 1050 ppm).

Strong inhibition potency of KBCE on the growth of $A$. hydrophila caused by ketapang bark ( $T$. catappa) contained active materials such as saponins, triterpenes, tannins, alkaloids, glycosides, and flavonoids. The roles of those chemical compounds were antibacterial (saponin), hemostatic and astringency (tannin), analgesic (alkaloids), anti-inflammatory (iridoid glycosides compound), and antioxidants and anti-inflammatory (flavonoids) (Masuda et al., 1999). Phenol compound and its derivatives (flavonoids) were some of the antibacterial that worked by interfering the function of the cytoplasmic membrane. At low concentrations, it could damage the cytoplasmic membrane which later on could cause the leak of important metabolites that inactivated bacterial enzyme system. Meanwhile, at high concentrations it could damage the cytoplasmic membrane and precipitated the cell protein (Volk and Wheeler, 1984).

Low inhibitory zone indicated that there has been dose of materials resistance towards $A$. hydrophilia. Therefore, that dose has not been able to damage or kill the cells of the bacteria. According to Pelczar and 
Chan (1986), the resistance that occurs in an organism towards the concentration of a substance is a natural mechanism to defend a life. Based on the length of inhibition time which was less than 24 hours, the inhibiting mechanism was categorized as bacteriostatic inhibition.

\section{Erythrocyte and Leucocytes Cells}

Observation on blood cells of carp (C. carpio) was conducted on the number of erythrocyte and leukocyte. The examined object was observed by using a binocular microscope with a magnification of 400x. Result showed that number of erythrocytes were 224.67×10, 332.67×10, and $417.00 \times 10$ cells $/ \mathrm{mm} 2$ for 730,750 and $770 \mathrm{ppm}$ $\mathrm{KBCE}$, respectively. In case of leukocytes were $735.89 \times 10$, $684.78 \times 10$, and $652.67 \times 10 \mathrm{cell} / \mathrm{mm} 2$ for 730, 750 and 770 ppm KBCE respectively (Figure 3 ). According to Monera and Simon (2008), erythrocytes are abundant blood cells in vertebrates. The main function of erythrocytes was for gas exchange (breathing). Structurally, according to Takashi and Hibiya (1995) red blood cells (erythrocytes) in fish have a core, generally it is round and oval depending on the type of fish. Some species had an oval-shaped red blood cells with a diameter of 11-14 $\mu \mathrm{m}$ and had a core with cells volume ratio and the core was 3.5 to $4.0 \mu \mathrm{m}$. The number of red blood cells in species were also different. Based on ANOVA test, erythrocytes showed highly significant differences between treatments.

Fig. 2 showed that the total average of erythrocytes and the use of dose was directly proportional; the higher the dose of the extract given, the more erythrocyte in Carp. This indicated that the active ingredient in KBCE was able to effectively inhibit or kill the A. hydrophila which infected the carps. Then, it decreased the bacteria so the inflammation process could be immediately stopped. The impact of the inflammation stopped was indicated by the increasing

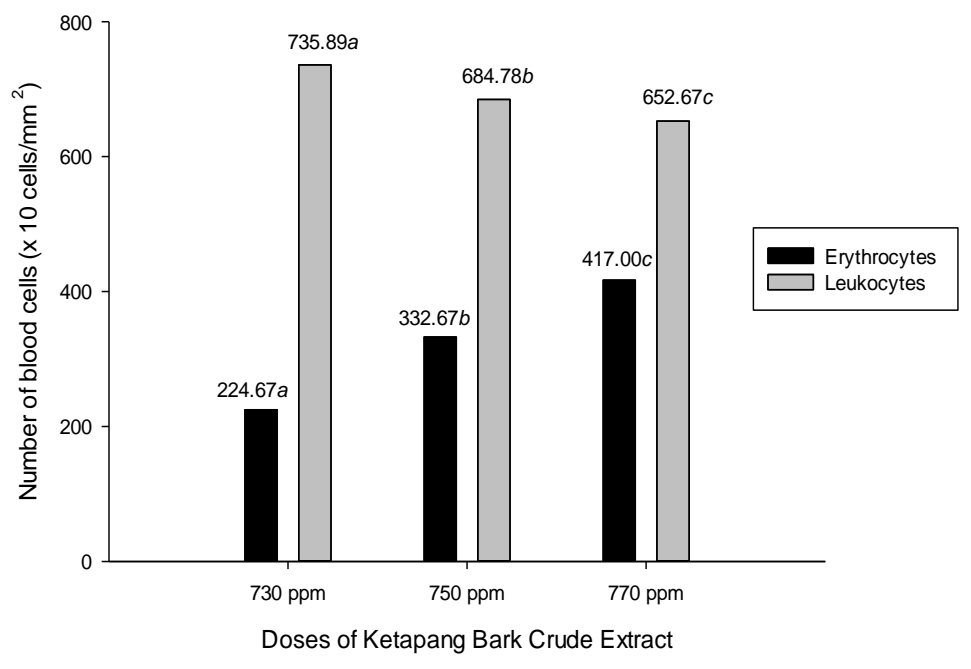

Fig. 2. The Relationship between doses of Ketapang bark crude extract and number of blood cells on Erythrocytes and Leucocytes. Data are represented as mean $(n=9)$.

Different letters indicate significant differences $(P<0.01)$ among three treatments determined by one-way ANOVA and continued by LSD 5\%. 
number of erythrocytes and then leukocytes decrease. This statement was in line with Volk and Wheeler (1984), phenolic compounds and their derivatives has anti-bacterial characteristic which kill bacterial cells.

According to Kapoor and Khanna (2004), there are two types of white blood cells found in the fish, eosinophils and granulocytes; each of them was one type of neutrophil, granulocyte, lymphocyte, monocyte, and thrombocyte. Leukocytes were the important component in the immune system of fish. The leukocytes production would be directed towards the infected areas as the form of fish defense mechanism. Based on ANOVA test, leukocyte cells indicated significant differences among treatments ( $p$ $<0.01)$. The relationship between the different doses and the total erythrocytes could be seen in Fig. 2 .

The Figure 3 showed that the total average of leukocytes and the dose was inversely proportional; it indicated that the higher dose of KBCE reduced the number of leukocytes in Carp. It could be explained as a mechanism of inflammation decrease as a form of the cessation of infection caused by bacteria or A.hydrophila due to inhibition of bacteria by giving KBCE that contained anti-bacterial active compounds. In line with the statement from Suhermanto et al., (2011), the rise in the number of leukocytes is an indicator of an infection which can cause inflammation, reversely the decline was due to the expiration of the infection process.

In other cases, Maftuch et al., (2012) and Maftuch et al., (2013) stated that the decrease in blood cells on the shrimp (which is the same function as leukocytes in fish) is because the physiological condition of shrimp which is no longer able to produce haemocytes. In this condition, the shrimp was already in a state of chronic infection as a result of the infection. Meanwhile, in this study the fish was not in the state of chronic infection, it was proven with the continuous increase of erythrocyte cell production as shown with dose and time increase. It could be concluded that the reduction in leukocyte cell was due to inflammation decrease in the body of the carp, as the effect of the cessation of the infection due to death of infecting bacteria by giving of KBCE. This evidence would be explored more in histopathological explanations after the use of the extract.

Water quality parameters during the research was on the level of quality standards that temperature, $\mathrm{pH}$ and $\mathrm{DO}$ ranged from 24.0 to $25.9 \square \mathrm{C}$, from 7.0 to 7.7 and from 3.9 to $4.8 \mathrm{mg} / \mathrm{L}$ respectively (Bhatnagar and Devi, 2013)

\section{CONCLUSION}

It can be concluded KBCE had bacteriostatic effect on $A$. hydrophila. Ketapang bark crude extract with $770 \mathrm{ppm}$ dose was possible to cure post infection of $A$. hydrophila because it could increase the total of erythrocytes together with the decrease of leucocytes (inflammatory cells) in carp (C. carpio).

\section{RECOMENDATION}

For further research, the histopathology test of carp (C. carpio) is expected to be conducted in order to know the histopathology level of recovery after cure. 


\section{REFERENCES}

Akinyemi, K.O. Oluwa, O.K., Omomigbehin, E.O. (2006). Antimicrobial Activity of Crude Extracts Of Three Medicinal Plants Used In South-West Nigerian Folk Medicine On Some Food Borne Bacterial Pathogens. Afr. J. Trad. CAM, 3 (4), 13 22

Bhatnagar, A. and Devi, P. (2013). Water quality guidelines for the management of pond fish culture. Inter J Environ Sci, 3(6), 1980-2009.

Bondad M.G, Subasinghe R.P, and Arthur, J.R. (2005). Disease and healthmanagement in Asian aquaculture. Veterinary Parasitology, 132 (3-4),249272.

Cipriano R.C. (2001). Aeromonas hydrophila and motile Aeromonad septicemias of fish. Fish Dis Leaflet 68, United States Department of the Interior fish and wildlife service, Division of Fishery research. Washington, DC. pp.1-25.

Gusrina. (2008). Aquaculture. Dorectorate of Vocational High School. Directorate of Technical and Vocational Education, Directorate General for Primary and Secondary Education, Ministry of National Education. Jakarta. Vol. 3.(In Indonesia).

Harborne, A.J. (1998).

Phytochemical Methods: a Guide to Modern Tecniques of Plant Analysis. Springer.
Kapoor, B.G. and Khanna, B. (2004). Ichthyology Handbook. Springer Verlag. New York.

Maftuch, E Prasetio, Murachman, A Sudianto, M Rozik, R Nurdiyani, E Sanusi, H Nursyam, F Fariedah, Marsoedi. (2013). Improvement of innate immune responses and defense activity in tiger shrimp (Penaeus monodon Fab.) by intramuscular administration of the outer membrane protein Vibrio alginolyticus. SpringerPlus, 2, 432.

Maftuch, M.H. Toban, Y. Risjani. (2012). Administration of marine algae (Gracilaria verrucosa) immunostimulant enhances some innate immune parameters in black tiger shrimp (Penaeus monodon Fabricus) against Vibrio harveyi infection. Journal of Applied Sciences Research, 8(2), 1052-1058, 2012.

Masuda T, Yonemori S, Oyama Y, Takeda Y, Tanaka T, Andoh T. (1999). Evaluation of the antioxidant activity of environmental plants: Activity of the leaf extracts from seashore plants. J Agric Food Chem, 47,1749-54.

Ministry of Marine Affairs and Fisheries (MMAF).(2015). The submission ofmeeting of the Ministry of Marine Affairs and Fisheries with the House of Representatives. Senayan. Jakarta. 
Monera, D. and Simon A. (2008). The Impact of Toxic Heavy Metals on The Hematological Parameters in Common Carp (Cyprinus carpio). Journal Environment, 6 (1), 23-28.

Mones, R. A. (2008). Description of Blood Cells in Carp (Cyprinus carpio) Majalaya Strain Originating from the Regional Ciampea. Thesis. IPB. Bogor.

Pelczar, M. J., and E. C. S. Chan. (1986). Microbiology. McGraw-Hill. New York.

Prihanto, A.A., Firdaus, M., Nurdiani, R. (2012). Anti-Methicillin Resistant Staphylococcus aureus (MRSA) of Methanol Extract of Mangrove Plants Leaf: Preliminary Report. Drug Invention Today, 4(8), 439-440

Purwani, K.I., Alami, N.H., Nurhatika, S., Marcilia, S.N., Arifiyanto, A. (2015). In Vitro Potential Test of Ketapang (Terminalia catappa) Leave Extract against Aeromonas salmonicida. J. Appl. Environ. Biol. Sci., 5(7), 1-6

Riskitavani, D.V and K.I Purwani. (2013). Study of Bioherbisida Leaf Extract Ketapang (Terminalia catappa) against nutgrass (Cyperus rotundus). Department of Biology, Faculty of Mathematics and Natural Sciences, the Institute of Technology (ITS). Page: 21 -22. (In Indonesia).

Shak, J.R, Whitaker, JA, Ribner B.S, Burd, E.M. (2011). Aminoglycoside-Resistant Aeromonas hydrophila as Part of a Polymicrobial Infection Following a Traumatic Fall into Fresh
Water. J Clin Microbiol, 49, 1169-1170.

Snieszko, S. F. (1973). Recent advances in scientific knowledge and developments pertaining to diseases of fishes. Advances in Veterinary Science and Comparative Medicine, 17, 291-314.

Suhermanto, A, S. Andayani and Maftuch. (2011). Giving of Phenol Total from Sea Cucumber (Holothuria scabra) to Improve Leukocyte and Differential Leukocyte of Carp (Cyprinus carpio) infected by Aeromonas hydrophila. Journal of Marine, 4 (2), 49-56.(In Indonesia).

Sumino., A. Supriyadi and Wardiyanto. (2013). Effectiveness of Leaf Extract Ketapang (Terminalia catappa L.) for the treatment of infections Aeromonas salmonicida on Catfish (Pangasioniodon hypophthalmus). JSV, 31 (1), 79-88.

Takashi. F. and T. Hibiya. (1995). An Atlas of Fish Histology Normal and Phatology Feature. Kodansha Ltd. Tokyo.

Thomsons, A., and Evans. (2006) The Potential of Terminalia catappa (Almond) and Hyphaene thebaica (Dum Palm) Fruits as Raw Material for Livestock Feed. African Journal of Biotechnology, 7 (24), 4576-4580.

Volk, W.A dan M.F. Wheeler. (1984). Basic Microbiology. Fifth Edition. Erlangga. Jakarta. $343 \mathrm{pp}$. 